\title{
RELATIONSHIP COACHING SUATU PENDEKATAN PENINGKATAN KUALITAS HUBUNGAN
}

\author{
Rena Latifa \\ UIN Syarif Hidayatullah Jakarta, Indonesia \\ E-mail: rena.latifa@uinjkt.ac.id
}

\begin{abstract}
Coaching is described as a structured human development process, the presence of focused interactions and the use of appropriate strategies, and tools and techniques to promote desirable and sustainable change for the benefit of clients (Bachkirova et al., 2014). The coaching process can explore the basic human need for relationships, by finding, developing and maintaining relationships with others. Relationship coaching is a form of coaching done in the context of improving or improving the quality of relationships between people. Relationship coaching is based on the formation of an individual's framework of thinking in reflecting on meaningful social relations experiences, using the basic principles of coaching. This paper is a review of relationship coaching techniques using several approaches, including RELATE and GREATER forms.
\end{abstract}

Keywords: relationship coaching techniques review; coaching; relationships with partners

Abstrak. Coaching digambarkan sebagai proses pengembangan manusia yang terstruktur, adanya interaksi yang fokus dan penggunaan strategi yang tepat, serta alat dan teknik untuk mempromosikan perubahan yang diinginkan dan berkelanjutan untuk kepentingan klien (Bachkirova et al., 2014). Proses coaching dapat mengeksplorasi kebutuhan dasar manusia untuk berhubungan, dengan cara mencari, mengembangkan dan menjaga hubungan dengan orang lain. Relationship coaching adalah bentuk coaching yang dilakukan dalam konteks perbaikan atau peningkatan kualitas hubungan antar manusia. Relationship coaching didasarkan pada pembentukan framework (sistem berpikir/sudut pandang) individu dalam merefleksikan pengalaman-pengalaman relasi sosialnya yang bermakna, menggunakan prinsip-prinsip dasar coaching. Tulisan ini merupakan review tehnik relationship coaching menggunakan beberapa pendekatan, diantaranya bentuk RELATE dan GREATER.

Kata Kunci: review teknik relationship coaching, coaching; relasi dengan pasangan

Permalink/DOI: https://doi.org/10.15408/mimbar.v36i2.14183 


\section{Pendahuluan}

Keinginan untuk memiliki hubungan personal yang dekat dianggap sebagai motif dan kebutuhan dasar manusia dan hal itu merupakan kunci faktor dalam kualitas kehidupan. Manusia memiliki drive untuk membentuk dan menjaga setidaknya jumlah minimum lamanya hubungan, hubungan positif, dan hubungan interpersonal. Salah satu bentuk hubungan yang dapat dibina pada fase dewasa adalah hubungan pernikahan.

Baumeister dan Leary (1995: 497) menyatakan bahwa manusia memiliki dorongan untuk membentuk dan mempertahankan setidaknya hubungan interpersonal yang positif dan signifikan. Tidak mengherankan kemudian, sukses atau kegagalan sehubungan dengan hubungan tersebut secara signifikan mempengaruhi kepuasan hidup (Myers dan Deiner 1995), kesejahteraan psikologis (Schwarzer dan Leppin, 1992), dan kesehatan fisik (Kaplan dan Manuck 1994). Sehingga, hubungan yang sukses adalah penyebab kegembiraan besar, seperti rasa koneksi yang mendalam. Namun, ketika hubungan itu berjalan salah dapat menjadi sumber dari beberapa kesulitan terbesar dalam hidup, termasuk depresi dan pembunuhan (Cupach dan Spitzberg 2011).

Sebagai disiplin ilmu yang memelihara kemajuan manusia, coaching secara alami sesuai untuk mendukung individu dalam memenuhi kebutuhannya dalam hal pemenuhan dan keberhasilan hubungan. Coaching digambarkan sebagai proses pengembangan manusia yang terstruktur, adanya interaksi yang fokus dan penggunaan strategi yang tepat, serta alat dan teknik untuk mempromosikan perubahan yang diinginkan dan berkelanjutan untuk kepentingan klien (Bachkirova et al., 2014). Proses coaching dapat mengeksplorasi kebutuhan dasar manusia untuk berhubungan, dengan cara mencari, mengembangkan dan menjaga hubungan dengan orang lain.

International Coach Federation (ICF) mendefinisikan coaching sebagai "hubungan kemitraan dengan individu melalui proses kreatif yang ditujukan untuk memaksimalkan potensi personal dan atau profesional individu." Coaching melibatkan proses kreatif dimana individu diajak untuk berpikir, menemukan ide-ide, dan membuat strategi. Coaching membuat individu sadar terhadap potensi dan kekuatan yang dimilikinya dan memiliki kemauan untuk memaksimalkan potensi tersebut. Melalui teknik mendengarkan, bertanya dan menggali, seorang coach membantu individu untuk menemukan potensi dan kekuatan dari dalam dirinya, yang diarahkan untuk mencapai suatu tujuan.

Relationship coaching adalah bentuk coaching yang dilakukan dalam konteks perbaikan atau peningkatan kualitas hubungan antar manusia, dapat berbentuk hubungan persahabatan, hubungan orang tua - anak, pacaran, hingga pernikahan. Relationship coaching didasarkan pada pembentukan framework (sistem berpikir/sudut pandang) individu dalam merefleksikan pengalaman-pengalaman relasi sosialnya yang bermakna.

Proses relationship coaching melibatkan hubungan pembinaan, memadukan aspek-aspek kunci dari goal focused coaching dan developmental coaching, merumuskan pendekatan untuk pembinaan yang berfokus pada masalah didefinisikan - mencari hubungan yang berjangka panjang -dan melalui proses ini melatih kesadaran dan juga kemajuan pribadi. Relationship coaching tidak berusaha untuk 
mengubah individu. Individu ditantang untuk mengeluarkan potensinya dalam mengatasi beberapa masalah mendasar. Tujuan utama relationship coaching adalah untuk memastikan bahwa coachee memiliki syarat sikap dan keterampilan yang tepat untuk dapat sukses dalam suatu hubungan.

Terdapat lima sikap umum atau persepsi dari individu dalam membangun suatu hubungan dan setelah beberapa kali membangun hubungan namun gagal untuk mempertahankan, yakni: 1) berkonflik atau kebingungan prioritas dalam apa yang sedang dicari dari pasangan, seperti kepribadian, atau mencari seseorang yang memiliki kesamaan dan berbeda dari diri mereka sendiri, 2) kesalahpahaman, yakni reaksi atau perilaku yang muncul karena lemahnya kesadaran diri, sehingga memunculkan reaksi negatif dari pasangan. 3) kaku dan sulit berkompromi, padahal suatu hubungan membutuhkan aspek saling ketergantungan, 4) kegagalan untuk mengatasi kekecewaan saat menemukan ketidaksempurnaan pasangan, hal ini dapat mengarahkan pada keretakan hubungan, 5) buruknya manajemen konflik ketika miskomunikasi, berkonflik atau harapan yang tak terekspresikan, atau saat kebodohan menimbulkan ancaman bagi hubungan yang sedang dijalankan.

Beberapa penelitian terkait keterampilan mengelola hubungan masih terbatas, padahal dibutuhkan ketrampilan untuk dapat membentuk dan menjalin hubungan hangat yang sukses berkelanjutan. Keterampilan berkomunikasi menjadi point dalam ketrampilan mengelola hubungan ini, dimana dengan ketrampilan ini akan mengurangi atau mengendalikan konflik dan meningkatkan kepuasan dalam suatu hubungan. Sebagai contoh John Gottman (1994) pernah menguraikan tentang manajemen konflik dimana ketrampilan ini dapat melatih cara individu melihat pola argumen yang tidak sehat dan bagaimana mengelola ketidaksetujuan dengan maksud menuju perbaikan hubungan dan mencegah kerusakannya. Berdasarkan hal ini maka relationship coaching yang diterapkan pada coachee dapat mengidentifikasi kesenjangan dalam sikap untuk meningkatkan kualitas hubungan atau keterampilan mengelola hubungan, dan dapat juga dijadikan sarana pengembangan pribadi.

\section{Pembahasan}

\section{Coaching dan Relationship Coaching}

Arnold (2009) menjelaskan bahwa coaching merupakan cara untuk mendorong seseorang dalam mencapai suatu tujuan dan mampu mengembangkan diri untuk memperoleh suatu keterampilan, sehingga praktek coaching harus berfokus pada upaya mendukung seseorang untuk bergerak maju serta bertanggung jawab terhadap keputusan dan tindakan mereka sendiri.

Sills (2003) menjelaskan bahwa dalam praktek coaching membentuk sebuah hubungan yang bermakna seperti empati, saling menghormati, dan saling memahami merupakan hal yang sangat penting untuk dilakukan oleh seorang coach terhadap coachee.

Coaching digambarkan sebagai sebuah proses pengembangan manusia yang memerlukan 'struktur, berfokus pada interaksi dan mengunakan strategi yang sesuai, alat-alat dan teknik yang diperlukan dan perubahan yang berkelanjutan yang berguna bagi klien dan mungkin untuk yang 
lainnya. Peran coach yaitu 'memfasilitasi klien untuk belajar menemukan jawaban-jawaban mereka sendiri. Coaching digunakan untuk mengatasi masalah dan memperkuat hubungan mereka. Coaching dapat digunakan untuk mendukung individu dalam krisis pernikahan atau kesulitan yang muncul dalam hubungan pernikahan.

Miser \& Miser (2008) menyebutkan 'coaching merupakan sebuah paradigma mengenai kemungkinan dimana coach adalah seorang kolaborator dengan pasangan yang sedang merancang dan menciptakan kehidupan yang ingin mereka capai. Memerlukan 'suasana yang baru terkait komunikasi, pemecahan masalah, negosiasi peran, dan tanggungjawab, menyelesaikan konflik, merencanakan dan mengambil tindakan bersama, serta menyarankan mengenai situasi yang mereka perlukan untuk 'meilhat dunia dari perspektif baru, sadar akan kehidupan yang mereka inginkan, penjabaran mengenai tujuan mereka, merencanakan kesuksesan bersama, dan belajar dari pengalamannya'.

Fitur khas Relationship Coaching adalah bahwa dimana teori-teori yang digunakan untuk memfasilitasi pengembangan, maka coach akan selalu berbagi pengetahuan tersebut sangat terbuka dengan klien. Pengetahuan dan pemahaman tentang teori-teori psikologis dan perkembangan adalah penting bagi coach karena, dalam mendukung pencapaian tujuan.

Dalam konteks hubungan (relationship), Nelson Jones berbicara tentang tiga tingkat kesejahteraan klien: mereka yang membutuhkan bantuan perbaikan (remedial), mereka yang memiliki hubungan yang cukup normal (normal), dan mereka yang mencari pertumbuhan (growth). Menggunakan tingkat ini akan membantu untuk memperjelas fungsi Relationship Coaching, seperti yang dijelaskan berikut ini:

- Remedial: Sampai saat ini, kebanyakan orang hanya mencari intervensi dari luar ketika mereka mengalami krisis hubungan. Bagi orang-orang yang membutuhkan bantuan untuk memperbaiki masalah yang signifikan dalam hubungan mereka, konseling mungkin memang menjadi intervensi yang paling tepat. Ini akan menguntungkan mereka untuk mengeksplorasi secara rinci akar penyebab masalah dan mulai mengeksplorasi mana solusi yang mungkin ditemukan. Mungkin ada masalah psikologis yang mendasari untuk satu atau lainnya yang mempengaruhi hubungan dan yang cukup serius yang memerlukan intervensi psikologis. Namun, dalam beberapa kasus, Relationship Coaching bisa juga berguna, terutama untuk membantu seseorang untuk mendapatkan tantangan untuk mengatasi blok yang menghalangi kemajuan mereka menuju hubungan yang langgeng.

- Normal: Sampai sesuatu mendorong mereka, orang-orang dalam kategori ini biasanya menganggap bahwa mereka tidak perlu mengubah apa pun dalam hubungan mereka atau bahwa perjuangan mereka adalah bentuk intervensi. Mayoritas orang lajang, pasangan, dan orang tua mungkin menganggap bahwa segala sesuatu adalah 'normal' bagi mereka, bahkan jika mereka mengalami kesulitan yang cukup besar. Mungkin mereka mengakui bahwa ada yang tidak berhasil di satu atau lebih area hubungan mereka, tapi mereka tidak menganggap itu sebagai krisi hubungan. Mereka mungkin pada awalnya melihat bahwa program Coaching tidak perlu, karena dalam pikiran 
mereka tidak ada yang salah dengan bagaimana hubungan mereka berfungsi, padahal mereka menerima gangguan rutin dan ketidakpuasan. Orang-orang ini biasanya tidak perlu konseling karena tidak ada masalah yang mendalam untuk dipahami atau diatasi, tapi mereka bisa mendapatkan keuntungan dari program Coaching untuk membantu mereka mengatasi masalah yang mereka hadapi dalam hubungan mereka.

- Growth: Di sini, program Coaching dapat dimanfaatkan untuk meningkatkan dan mengembangkan hubungan untuk mencapai potensi penuh atau meningkatkan kemampuan seseorang untuk membentuk atau mengamankan hubungan yang abadi.

Relationship Coaching merupakan perpaduan dari berbagai jenis Coaching, khususnya yang berfokus pada tujuan (goal-focused coaching) dan perkembangan (developmental coaching), sebagai pendekatan yang penting untuk digunakan dalam kombinasi, dalam mendukung konteks hubungan. Relationship Coaching sebagai goal-focused coaching harus menekankan pada membangun tujuan yang jelas dan menciptakan rencana aksi yang efektif untuk mencapai tujuan, serta merangkul banyak fitur lain dari pendekatan fokus pada tujuan, seperti kebutuhan untuk melakukan brainstorming untuk solusi kreatif .

Namun, Relationship Coaching sebagai developmental coaching juga merupakan perkembangan sepanjang arah mencapai tujuan untuk mendorong pengembangan pribadi dan sikap, serta pengembangan keterampilan. Fokusnya adalah pada mempertahankan hasil dari waktu ke waktu, daripada mencapai sesuatu hasil yang 'Cepat'. Sedangkan pengembangan pribadi umumnya tidak seketika atau bahkan dilihat, maka Relationship Coaching perlu untuk mencapai kemajuan yang jelas dan segera. Sementara perkembangan itu sendiri adalah bertahap dan organik (Cox dan Jackson 2014), tetapi Relationship Coaching tidak bisa menjadi proses seumur hidup.

Sehingga, Relationship Coaching dalam pendekatan goal-focused coaching, bertujuan untuk membantu klien dalam mengubah tindakan mereka (Eksternal). Selanjutnya, dengan perpaduan pendekatan developmental coaching, bertujuan untuk membantu mereka mengubah sikap mereka (Internal) - untuk mengubah perspektif mereka. Oleh karena itu, Relationship Coaching berfokus juga dalam menganalisis dan memecahkan masalah, tetapi juga mengakui bahwa rute menuju hasil positif melalui wilayah pengembangan pribadi (Ives 2012). Sedangkan pendekatan goal-focused coaching, pada dasarnya adalah tentang meningkatkan kinerja dan mendukung tindakan yang efektif, dan pendekatan developmental coaching berfokus pada mengatasi perasaan dan menghasilkan refleksi (Ives dan Cox 2012) untuk mencapai transformasi.

Teknik relationship coaching adalah menggali potensi-potensi kreatif apa saja yang dimiliki oleh coachee, sehingga melalui potensi tersebut dapat terwujud perubahan sikap dan perilaku. Metodenya mengusung prinsip pembelajaran orang dewasa, yang mengutamakan keterbukaan dan mengeksplorasi pengalaman dan pemaknaan coachee atas pengalamannya tersebut (Knowles, Holton \& Swanson, 2005). Kesuksesan seseorang dalam mencapai tujuan hidup sangat dipengaruhi oleh pola hubungan atau kemitraan yang dibangun terhadap lingkungan sekitarnya dan Relationship coaching menjadi 
metode yang efektif dan fleksibel untuk meningkatkan kemampuan seseorang dalam membangun pola hubungan atau kemitraan yang baik dan bisa diterima. Dalam hubungan, orang sering harus mengubah pandangan mereka dan bahkan mengubah perasaan mereka, yang membutuhkan pendekatan perkembangan.

Ives (2012) menjelaskan bahwa dengan praktek coaching, permasalahan yang dialami oleh coachee menjadi lebih mudah untuk diidentifikasi penyebabnya, sehingga praktek coaching diharapkan dapat memberikan pengalaman belajar dan perubahan sikap bagi coachee. Menurut Ives (2012), banyak dari individu yang mengeluhkan kesulitan dalam menjalin hubungan dikarenakan tidak dapat menemukan mitra yang cocok.

\section{Kombinasi Goal-focused dan Development}

Coachee mendatangi relationship coach dengan harapan mendapat bantuan mengenai tujuan utamanya yakni -dapat menjalin hubungan yang tahan lama dan berkualitas-, sehingga dalam hal ini pendekatan coaching dapat ditekankan kepada pembinaan Goal-focused. Namun, seperti yang dijelaskan di atas asumsi relationship coaching harus memiliki unsur refleksi dan pembelajaran, oleh karena itu dalam relationship coahing juga harus memanfaatkan kekuatan dari pendekatan developmental coaching.

Goal focused coaching. Didefinisikan sebagai "sebuah intervensi pertolongan yang sistematis dan kolaboratif dan non-direktif, goal focused berbasis pada dorongan performa, dimaksudkan untuk memfasilitasi lebih efektif menciptakan dan mengejar tujuan" (Ives \& Cox, 2012). Fungsi utama membantu self-regulasi coachee, membantu regulasi individu dan mengarahkan sumber daya interpersonal dan intrapersonal mereka untuk dapat lebih baik mencapai tujuan mereka (Grant 2006 p. 153). Metode utama adalah membantu coachee untuk mengidentifikasi dan membentuk tujuan yang disusun dengan baik dan mengembangkan keefektifan dalam membuat rencana (Ives, 2008). Peran coach di sini adalah untuk menstimulasi ide-ide dan tindakan dan untuk memastikan bahwa tujuan konsisten dengan kehidupan coachee, nilai-nilai dan kepentingan, daripada membantu coachee untuk menyesuaikannya/nilai-nilai dan keyakinannya. Dalam konsepsi ini, pembinaan ditujukan untuk meningkatkan kinerja dan mendukung tindakan yang efektif, bukan merujuk pada perasaan dan pikiran, namun diasumsikan secara tidak langsung akan tersampaikan/berefek melalui hasil yang positif (Grant, 2003). Hal ini bertujuan untuk mencapai hasil dalam jarak yang relatif singkat dan biasanya fokus pada pendefinisian masalah atau tujuan. Goal-focused coaching tidak bertujuan berusaha untuk menstimulasi perubahan psikologis (Cox, 2012), tidak terdorong oleh keinginan untuk memberantas disfungsi psikologis (Bachkirova, 2007), tetapi adalah alat untuk meningkatkan performa dalam menjalin hubungan. Sementara seiring dengan itu perubahan psikologis dapat terjadi (Ives 2010).

Tidak seperti banyak pendekatan coaching (misal Stober, 2006; Gray, 2006), goal-focused coaching tidak menganjurkan pendekatan holistik untuk mencapai tujuan, namun berfokus pada stimulasi tindakan yang efektif. Tidak terfokus pada menstimulasi perubahan internal (Hudson, 1999), tetapi bekerja untuk mengintegrasikan proses perubahan ke model perilaku harian. Tujuan goal-focused 
coaching mengadopsi forward focus, mengarahkan perhatian terhadap langkah-langkah praktis untuk mengarahkan coachee untuk maju atau melihat ke depan. Dengan menerapkan cara ini akan berdampak pada pengurangan kecemasan, membuat tugas tampaknya lebih mudah dikelola, dan meningkatkan buy-in dengan tujuan yang lebih nyata, dengan demikian lalu mendorong coachee lebih maju dan bersemangat (Ives \& Cox, 2012).

Ives (2010) menemukan bahwa menerapkan forward focused melalui penetapan tujuan dan perencanaan dapat menimbulkan penerimaan tanggung jawab pribadi, mendorong coachee untuk fokus dan berusaha untuk meningkatkan apa yang ia bisa, daripada mengeluh atau membuat tuntutan yang tidak efektif pada organisasi nya. Dalam goal-focused coaching, sisi negatif mengarahkan secara tidak langsung terhadap sesuatu yang lebih nyata, berfokus pada hasil-hasil kecil dan hasil praktis yang diinginkan (Szabo \& Meier,2009). Dengan menetapkan tujuan yang jelas, individu akan difokuskan pada pencapaian tujuan dan cenderung untuk tidak terlibat dalam kegiatan yang dapat mengalihkan perhatian dari usaha mencapai tujuan.

The forward-focus dalam goal-focused coaching bukan untuk secara penuh mengesampingkan pertimbangan masa lalu, dan mencari solusi bukan dengan menghilangkan pemahaman yang tepat dari masalah (Bachkirova 2007). Namun, fokus utama pada pembinaan ini adalah masa sekarang dan masa depan yang diharapkan coachee (O'Connell \& Palmer 2007, p. 280). Langkah awal yang dilakukan coachee, sekalipun kecil, diperlukan untuk menciptakan platform untuk kemajuan, dan self-efficacy coachee dibangun atas pengalaman sukses sebelumnya (Cox, 2006 p. 204). Tindakan nyata menciptakan pengalaman positif yang pada akhirnya akan mengarahkan ke pilihan tindakan yang positif (Parsloe \& Wray2000; Berg \& Szabo, 2005).

Developmental coaching - Sebaliknya, pembinaan perkembangan berfokus pada pengembangan diri daripada self-regulation. Banyak coach (Chandler \& Kram, 2005; Fitzgerald \& Berger, 2002; Berger, 2006; Laske, 2006a, 2000b) telah mendasarkan pendekatan mereka pada teori perkembangan dewasa yang mengadopsi pendekatan yang lebih holistik terhadap pertumbuhan dan kematangan coachee, daripada fokus pada peforma hubungan. Pengembangan pribadi dapat merujuk pada pertumbuhan seseorang secara keseluruhan dalam semua hal yang ia bisa. Namun, pada praktiknya developmental coaching hanya dapat fokus pada aspek tertentu dari seseorang. Parameter pembinaan perkembangan harus bergantung pada persyaratan coachee dan situasi.

Setiap jenis pembinaan pengembangan pribadi didasarkan pada keyakinan atas kemampuan dan potensi orang tersebut dan memberikan kesempatan untuk mengembangkan kemampuan dan potensinya. Sebagaimana Cox dan Jackson (2010) berpendapat, dalam developmental coaching tidak hanya fokus pada pemecahan masalah tetapi juga untuk memastikan bahwa membangun kapasitas klien melalui pemecahan masalah. Secara umum perkembangan mengacu pada pertumbuhan dan perubahan dari waktu ke waktu, seperti apa yang Cox dan Jackson sebut sebagai elemen 'progresif. Menurut Cox dan Jackson (2010) pendekatan developmental coaching, mengarah kepada kebutuhan, berjangka panjang, perspektif yang lebih evolusioner. Demikian pula, Berman dan Bradt (2006, p. 245) menunjukkan bahwa intervensi pribadi melalui developmental akan relatif berjangka panjang. 
Developmental coaching membutuhkan waktu yang lebih banyak karena kemajuan internal psikologis adalah inti dari prosesnya. Pendekatan developmental coaching membuka pembelajaran dari masa lalu yang dapat dipergunakan sebagai platform untuk perkembangan pribadi. Developmental coaching tidak tertarik dengan hasil yang cepat dan kemajuan nyata yang kecil tetapi lebih pada tujuan mendapat dampak yang signifikan atas keasadaran yang terbaharui dan peluang kemajuan. Cox dan Jackson (2010) menunjukkan bahwa perkembangan harus melibatkan kemajuan dan ekspansi dari beberapa jenis. Tergantung pada pendekatan atau target yang ingin dikembangan, kemajuan dan ekspansi akan sangat luas atau cukup sempit.

Developmental coaching memiliki dua bagian padangan. Pertama berakar pada teori perkembang life course dan seperti yang dijelaskan oleh oleh Palmer dan Panchal (2011). Pendekatan ini memperhitungkan bagaimana perubahan motivasi selama kehidupan dan menunjukkan bahwa coach harus menyadari hal ini dan masalah kehidupan lainnya. Pendekatan kedua didasarkan pada teori perkembangan konstruktif, yang mengklaim bahwa seseorang berkembang untuk dapat dapat lebih sadar dan terbuka atas pemahaman kekuasaan dan tanggungjawabnya. Pembinaan dari perspektif ini didasarkan pada gagasan tahapan perkembangan dan menunjukkan bahwa pembinaan pada setiap tahap perlu fokus pada tahap dari perkembangan itu sendiri dan isu-isu terkait (Bachkirova 2011; Bachkirova \& Cox, 2007, Berger, 2006).

Relationship Coaching merangkul banyak fitur dari goal-focused coaching, seperti kebutuhan untuk brainstrorm untuk menghadirkan solusi yang kreatif dan mendapatkan keterampilan dan strategi yang dibutuhkan. Dalam orientasinya, Relationship coaching juga memakai forward focused, walaupun memberikan pemahaman yang lebih dari masalah meskipun memberikan bobot yang lebih besar untuk pemahaman pembelajaran pengalaman masa lalu. Relationship coaching mengarah pada perkembangan pribadi dan perubahan perilaku untuk penambahan keterampilan. Memegang pendekatan developmental coaching yang mengacu pada perubahan dari waktu ke waktu daripada perubahan yang cepat. Pada relationship coaching juga memerlukan peningkatan yang nyata dan dilakukan dalam waktu yang cukup cepat, karena proses relationship coaching tidak dapat terjadi seumur hidup.

Relationship coaching adalah kognitif -behavior yang sejauh ini memfasilitasi kesadaran diri melalui eksplorasi dioalog internal dan pikiran otomatis. Coach juga dapat menggambarkan tehnik kognitif-behavior seperti mengeksplorasi keyakinan klien dan konsekuensi dari menganut keyakinan itu jika mereka tidak terlalu berhasil di masa lalu aktivitasnya tidak terasosiasi dengan goal focused coaching. Saya berpendapat bahwa pembinaan hubungan bisa disesuaikan dengan 'pembinaan transformasional', karena bertujuan untuk membantu coachee untuk berpikir dan bertindak berbeda dalam menanggapi dilema.

Sementara goal-focused coaching bertujuan untuk memodifikasi tindakan seseorang (eksternal), relationship coaching bertujuan untuk mengubah sikap seseorang (internal). Perbedaan ini mirip dengan teori Peltier (2001) dimana pembinaan dibagi menjadi dua kategori utama: pembinaan eksekutif (internal sikap) dan kegiatan pengelolaan sehari hari (eksternal). Terdapat beberapa kesamaan dengan Summerfield (2006) pembagian antara pembinaan 'acquisitional' (mengakuisisi kemampuan 
baru) versus pembinaan "transformasional ' (pribadi mengalami perubahan). Tujuan pembinaan berfokus pada meningkatkan kinerja dan mendukung tindakan yang efektif, sedangkan pengembangan pembinaan berfokus pada mengatasi perasaan dan menghasilkan refleksi yang mendalam (Ives \& Cox, 2012). Goal-focused coaching bertujuan untuk meningkatkan perubahan operasional, bukan dari restrukturisasi psikologis (Hall \& Duval 2004); hal itu diniatkan untuk mendukung peningkatan produktifitas dengan segera (Stewart, Palmer, Wilkin \& Kerrin,2008).

Relationship coaching memakai gaya eksplorasi dimana terdapat kegunaan yang lebih dari developmental coaching dan mengurangi pragmatis (Snyder, 1995). Hudson (1999 p. 20). Membentukan yang diharapkan adalah lebih ke peningkatan peforma yang memberikan fungsi daripada mendorong untuk mendapat perubahan mendasar. Relationship coaching memberikan analisis dengan pendekatan goal focused coaching tetapi juga merekognisi hasil yang positif melalui perkembangan pribadi pada areanya.

\section{Tumbuh Kembang Pribadi melalui Relationship Coaching}

Development coaching didasarkan pada literatur tentang kehidupan sepanjang perkembangan, misalnya oleh Erikson (1974) dan Levinson (1978). Relationship Coaching yang dijelaskan oleh Kegan (1994) menyebutkan bahwa perkembangan kognitif berfokus secara eksplisit pada bagaimana perkembangan pribadi memengaruhi kemampuan untuk membina hubungan yang lebih efektif. Kegan berpendapat "deskripsi yang lebih komprehensif dari struktur dasar yang menimbulkan munculnya suatu hubungan secara alami”. Kegan selanjutnya menunjukkan bagaimana persepsi hubungan orangorang ditentukan oleh apa yang mereka ambil untuk menjadi diri dan apa yang mereka ambil untuk menjadi orang lain dan hubungan di antara mereka -diistilahkannya 'hubungan subjek-objek'. Sebagaimana Bachkirova dan Cox (2007) menjelaskan: di dalam teori ini sesuatu yang dikatakan subjek didefinisikan oleh pengalaman yang tidak dapat dipertanyakan, suatu bagian dari diri. Sesuatu yang dikatakan subjek tidak dapat diobservasi karena ia adalah bagian dari individu itu, tidak dapat terefleksikan- akan dibutuhkan kemampuan untuk dapat melihatnya. Sementara itu sesuatu dikatakan subject adalah milik kita, dan kita memiliki sesuatu itu yang dikatakan objek.

Hal-hal yang menjadi 'objek' dalam hidup kita adalah 'unsur-unsur yang kita ketahui atau organisir bahwa kita dapat merenungkan, menangani, melihat, bertanggung jawab untuk, berhubungan dengan sama lain, mengendalikan, internalisasi, mengasimilasi, atau mengoprasikannya' (Kegan, 1994: 32). Dalam developmental coaching mengangkat peningkatan kesadaran tidak hanya membantu seseorang melihat hal-hal yang sebelumnya diabaikan, tapi selain itu untuk melihat hal-hal ini melalui pandangan yang berbeda.

Dalam nada yang sama, relationship coaching bertujuan untuk membantu coachee untuk dapat melakukan pendekatan sebagai 'objek', agar tindakan dapat pada cara mereka menangani hubungan bukannya menjadi yang dikendalikan oleh prasangka mereka. Sebagaimana Fitzgerald dan Berger (2002: 31) mengatakan: 'intervensi coach hanya membantu untuk menjaga wawasan kritis hidup untuk klien mereka. Peran utama dari relationship coach adalah untuk menunjukkan pemahaman coachee, 
tetapi juga menunjukkan pemahaman kepada coachee sebagaimana yang ia miliki dan pemahaman yang dapat diperbaharuhi (Kegan, 1982).

Ada dua cara pendekatan hubungan: yang pertama adalah 'cara sederhana', yang umumnya bagaimana orang memasuki hubungan ketika mereka masih muda dan fleksibel. Yang kedua memasuk ke dalamnya ranah yang lebih sadar, yakni tipe single yang tidak muda lagi. Maka masalah tidak dapat secara umum diabaikan, melainkan mereka perlu ditangani. Relationship coaching adalah tentang meningkatkan kemampuan coachee untuk berdiri kembali dan melihat lebih objektif pada kehidupannya.

\section{Model Relationship Coaching}

Kunci yang penting dari elemen developmental coaching adalah pengaruh perubahan permanen pada beberapa hal (Cox dan Jackson, 2010). Relationship Coaching tidak secara eksplisit mencari perubahan kognitif-struktural, yang merupakan proses panjang dan merupakan perubahan evolusi. Ahli perkembangan sendiri mengakui beragam cara-cara di mana orang berkembang (Bachkirova, 2010); dengan demikian, perubahan struktural kognitif bukan satu-satunya cara untuk membuat kemajuan, perubahan dapat terjadi tanpa itu.

Relationship Coaching secara intrinsik terikat dengan refleksi dan dioptimalkan melalui interaksi manusia, dengan membantu coachee menjadi lebih baik. Awal pemahaman tentang realitas sosial yang memengaruhi pemahaman mereka bahwa realitas sosial meningkatkan perkembangan kognitif. Dalam Relationship Coaching, kesuksesan diukur dengan "aplikasi berkelanjutan khususnya akan pengetahuan, keterampilan, sikap dan kualitas lain yang diperoleh selama proses coaching "(Stewart, Palmer, Wilkin \& Kerrin 2008 p. 32).

Model Relationship Coaching berdasarkan pada akronim RELATE. Langkah-langkah tidak bersifat linear secara kaku dan bergantung pada situasi dan gaya dari pelatih, beberapa langkah dapat saling melengkapi dan berinteraksi.

\begin{tabular}{|c|c|}
\hline R - Reality & $\begin{array}{l}\text { Memahami keadaan saat ini dan apa yang telah berlalu di masa } \\
\text { lalu }\end{array}$ \\
\hline E - Exploration & $\begin{array}{l}\text { Mendapatkan pemahaman yang lebih dalam pengalaman, } \\
\text { perspektif dan sikap coachee }\end{array}$ \\
\hline L - Leasson/Learning & $\begin{array}{l}\text { Mencoba mempraktikan dalam kehidupan nyata tentang apa } \\
\text { yang telah dan apa yang didapat coachee dari pembelajaran ini }\end{array}$ \\
\hline A - Action Plan & $\begin{array}{l}\text { Bagaimana coachee dapat bertindak secara berbeda dan } \\
\text { menghasilkan strategi }\end{array}$ \\
\hline T- TakeAction & Mengimplementasikan strategi baru \\
\hline E - Evaluate & Mereview dan menganalisis kemajuan yang telah dibuat \\
\hline
\end{tabular}


Reality -- Relationship Coaching adalah intervensi non-terapi, oleh karena itu berfokus pada masa lalu hanya untuk meningkatkan derajat kecenderungan orang untuk melakukan yang terbaik di masa depan. Dalam hal ini Relationship Coaching adalah pendekatan pembelajaran, sangat didasarkan pada pemahaman pelajaran yang bisa diperoleh dari pengalaman dahulu, sehingga pembinaan dimulai dengan Kegiatan pencarian fakta menyeluruh untuk menjelaskan apa yang telah berlangsung sampai saat ini.

Tahap 'realitas' mengacu beberapa tujuan penting. Membawa informasi kunci untuk masa depan coachee yang lebih baik, mengarahkan perhatian terhadap fakta tanpa dibarengi dengan emosi negatif, hal itu memungkinkan pelatih untuk mendapatkan pemahaman yang wajar pada situasi coachee dan yang terpenting, mendengarkan dengan hati-hati tanpa menghakimi kisah kehidupan coachee. membangun kepercayaan dan hubungan coachee dapat menjadi platform (dasar) untuk performa coachee yang penting untuk dilakukan (Whitmore, 2003).

Exploration - Setelah realitas, coach akan menggali, bertanya menyelidik dan bertanya untuk mengetahui alasan yang mendasari coachee dalam pilihan dan peristiwa penting dalam kehidupan relationshipnya. Dengan meletakan brainstorming sebagai pilihan, seperti yang telah kita tahu sebelumnya pada goal-focused coaching (Whitmore, 2003; Ives 2010), dalam Relationship Coaching brainstorming sebagai pelajaran dari pengalaman masa lalu. Ini adalah apa yang Goodman (2002 p. 138) sebut dengan 'meminta arti/asking for meaning'. Beberapa coach akan menemukan bahwa setelah pada tahap realitas, mereka menemukan manfaat dan makna dari pertanyaan 'eksplorasi'. Pada tahap realitas agar memberikan waktu pada coachee sehingga dapat terdorong kepada pertanyaan eksplorasi dan juga agar coach selalu mendengarkan lalu bertanya.

Leasson/Learning - Sementara tahap eksplorasi mungkin memiliki isi yang menarik dan berharga untuk pertumbuhan dan perubahan, dimana hal itu adalah tujuan pembinaan untuk mengetahui dimana letak 'masalah'. Coach bekerja sama dengan coachee untuk memahami dimana letak 'penyumbatan/blockage'. Model kendala, penghambat perkembangan dapat merugikan karena menyulitkan coachee mencapai tujuan. Tujuan pembinaan adalah untuk membuka hambatan, dan untuk memastikan perkembangannya; maka pembelajaran dilakukan secara dalam dan menyeluruh, dan memerlukan implikasi praktis.

Action Plan - tujuan relationship coaching bukan sekedar mencerahkan; namun meningkatkan kemampuan untuk membentuk dan mengamankan hubungan untuk dapat berjangka panjang. Oleh karena itu, Tahap penting selanjutnya adalah menciptakan rencana tindakan yang akan menentukan perubahan sikap dan perilaku apa yang dapat dibuat oleh coachee. Rencana tersebut dapat mencakup bacaan tambahan dan belajar atau pengembangan keterampilan, secara praktis. Tindakan yang didasarkan oleh rencana tindakan mencerminkan komitmen yang kuat dari pembinaan untuk memprioritaskan terciptanya masa depan yang lebih baik, dan tidak sedang terseret oleh frustrasi masa lalu. 
Coach dapat membantu coachee untuk menyusun rencana tindakan. Pertama, menanggapi komitmen yang lemah. Coach dapat memberikan dorongan dengan mengingatkan coachee mengapa titik tindakan ini dianggap penting dan dengan menyediakan dukungan umum (Ives, 2010). Denman menggunakan Kombinasi tujuan distal dan proksimal (Latham, 2007). Perencanaan jangka pendek menjadi penting untuk memastikan tujuan proksimal yang tepat dan sesuai keadaan (Baumeister \& Vohs, 2007), sedangkan gol distal memberikan konsistensi dan arah.

TakeAction - pada titik ini, coach harus telah membangun kredibilitas dan kepercayaan yang tinggi. Coach harus meminta pertanggungjawaban coachee untuk setiap tindakan dia berkomitmen dalam rencana tindakan tersebut. Jelas, seringkali coachee gagal mengimplementasikan rencana yang telah disepakati. Peran coach bukan merasa sedih, melainkan untuk melihat ini sebagai kesempatan belajar lebih lanjut dan untuk mendukung coachee dalam menemukan cara yang lebih efektif untuk berhasil dalam melaksanakan rencana yang telah dibuat.

Evaluate - Evaluasi - dalam coaching perlu adanya pengukuran kemajuan terhadap beberapa tolak ukur keberhasilan. Pembinaan harus membahas apakah coachee membuat kemajuan yang diinginkan, dan dia menyadari akan adanya keterampilan baru atau keberhasilan hubungan yang ia bina. Selain itu, coachee akan sering ingin kembali pada coach untuk meninjau situasi. Jika mereka yang masih single, mereka akan membahas strategi lebih lanjut, dan jika dalam hubungan pernikahan mereka biasanya ingin membahas hal-hal yang mengkhawatirkan mereka. Ini akan menjadi kesempatan untuk meninjau kembali sikap sebelumnya untuk menjelajahi bagaimana perubahan terjadi dan keterampilan mendukung dalam membina hubungan.

Ives (2012) juga menjelaskan jenis praktek coaching yang dilakukan untuk meningkatkan relationship didasarkan pada model GREATER, yaitu :

a. Goal, menetapkan tujuan umum dan khusus dari diadakannya praktek coaching.

b. Reality, memahami keadaan saat ini dan masa lalu.

c. Exploration, mencoba mendapatkan pemahaman yang lebih mendalam mengenai pengalaman, perspektif dan sikap dari coachee.

d. Action plan, membuat rencana aksi dan strategi yang harus dilakukan coachee.

e. Take action, melaksanakan tindakan dan strategi yang telah ditetapkan.

f. Evaluate, melakukan evaluasi dan menganalisis mengenai kemajuan praktek coaching.

g. Repeat, melakukan pengulangan apabila aksi tidak sesuai rencana atau tujuan yang diperlukan.

Relationship seseorang bisa dikembangkan dengan baik apabila praktek coaching yang dilakukan dengan sistematis, fokus, kolaboratif dan tidak memberikan intervensi langsung sehingga sikap serta tindakan yang muncul murni berdasarkan keputusan dari coachee. Dalam praktek relationship coaching seorang coach harus mampu merangsang ide dan tindakan coachee sehingga mampu untuk mencapai tujuannya. Bahwasanya melalui praktek relationship coaching seseorang 
didorong untuk bertanggung jawab secara pribadi untuk melakukan sebuah perubahan sikap dan metode ini terbukti efektif dalam meningkatkan kualitas hubungan seseorang.

Membantu individu dalam relationship coaching ditemukan dapat menghasilkan perubahan positif pada individu, kualitas hubungan, kesejahteraan dan komunikasi. Proses coaching ini juga dapat membantu individu mengelola sesuatu yang tidak terselesaikan, seperti trauma dari hubungan sebelumnya, hal ini menjelaskan bagaimana relational coaching berfokus pada hubungan yang dihadapi pada masa kini dan masa mendatang.

Relationship coaching berfokus pada cara membantu individu yang mengarah pada kebutuhan berhubungan mereka. Dalam konteks pasangan, coaching dapat memberikan ruang bagi pasangan mengenai bagaimana merefleksikan tekanan-tekanan yang mereka alami dan fokus untuk membentuk visi bersama mengenai bagaimana cara mengembangkan hubungan mereka. Dalam relationship coaching, pemberian saran sebaiknya dilakukan dengan cara selektif dan hati-hati. Berbagi ide mengenai pengembangan dan pembelajaran serta tujuan mengenai perspektif baru untuk pertimbangan klien.

Pendekatan coaching dikategorikan ke dalam 3 paradigma yang luas: goal-focused, developmental coaching, dan terapi. Relationshiip coaching merupakan perpaduan antara goal-focused dan developmental coaching. Dalam relationship coaching ada suatu perubahan dalam pola pikir. Individu sering mengubah pandangan mereka dan mengubah perasaan mereka, dan hal tersebut membutuhkan suatu pendekatan developmental. Konseling dan terapi berfokus pada 'mengeliminasi permasalahan psikologis dan disfungsi-disfungsi yang dialami', coaching berfokus pada 'meningkatkan kehidupan, memperbaiki performa'. Klien 'memeriksa dan mengevaluasi kehidupannya' dan kemudian membuat perubahan sistematis untuk meningkatkan kehidupannya dengan dukungan coach.

Dalam coaching, asesmen merupakan alat yang memungkinkan klien dan coach memahami konteks coaching, termasuk nilai-nilai dan tujuan klien. Penggunaan asesmen dalam relationship coaching adalah berdasar pada paradigma pragmatis, dimana coach memfasilitasi dalam mengeksplor tujuan mengenai pengalaman kehidupan klien agar dapat meningkatkan kehidupan klien dalam beberapa aspek.

Hasil dari penggunaan asesmen digunakan sebagai pedoman untuk klien dan memastikan bahwa target yang didapatkan sesuai dan tujuannya secara menyeluruh dapat terealisasi. Dengan berfokus pada peningkatan kehidupan klien, coaching melibatkan pengembangan ide, dan pegembangan strategi. 'Strategi dikembangkan, metode diseleksi dan hal ini diikuti dengan memilih intervensi dan perlakuan yang tepat'. Strategi hanya diseleksi melalui proses komunikasi terbuka dan sharing antara coach dan klien, dan mereka sangat berfokus pada pencapaian tujuan.

COUPLE (Komitmen, Keterbukaan, Pemahaman, Performa, Pembelajaran, Perubahan). Menggunakan kerangka ini, kita mengeksplor bagaimana coaching dapat meningkatkan hubungan pasangan melalui pemeriksaan nilai-nilai, keyakinan, dan asumsi serta keterbukaan dalam komunikasi. Hasilnya, pasangan mencapai pemahaman yang lebih mengenai diri mereka sendiri, mengenai pasangan 
mereka, dan hubungan mereka. Termasuk pendekatan 'pembentukan komunikasi' untuk membantu pasangan meningkatkan komunikasi mereka.

Bolstad (n.d) mengidentifikasi bahwa ketika pasangan melakukan coaching, mereka memiliki pengalaman serius, tidak bahagia, memiliki konflik yang tidak terselesaikan atau setidaknya salah satu pasangan merasa kesepian dan ada kebutuhan rasa cinta dan kedekatan yang belum terpenuhi. Salah satu pasangan mungkin tidak optimis mengenai apa yang perlu mereka buat untuk hubungan mereka. Coach merupakan 'sesuatu yang membantu mengidentifikasi dan memperpanjang lamanya hubungan dan mendukung klien meraih harapan mereka',

Sebagian besar penelitian empiris yang berfokus membantu pasangan dalam hal hubungan mereka yaitu dibahas dari bidang psikoterapi, dikutip dari penelitian Gottman (1999, 2011). Penelitian Gottman mendukung pendapat bahwa kebahagiaan dalam hubungan dilihat dari setiap pasangan melihat oranglain sebagai orang yang berguna dan melihat ketidaksetujuan sebagai ekspresi yang tepat bagi perbedaan. Pembentukan budaya di antara pasangan dan bagaimana budaya ini dan kualitas persahabatan di antara mereka yang mendukung hubungan yang sukses. Pendekatan dalam relationship coaching lebih kepada pembentukan dari visi bersama yang ingin dicapai oleh pasangan dibandingkan dengan eksplorasi daripada masalah yang terjadi saat itu. Untuk meningkatkan jumlah peristiwa positif dan emosi positif yang dialami bersama.

Konsep memaafkan sangatlah berguna dalam coaching pasangan, dimana penerimaan kesalahan-kesalahan yang dilakukan oleh pasangan menjadi kunci untuk meneruskan tugas coaching. Memaafkan merupakan proses penyembuhan dan salah satu proses yang paling kritis untuk memfasilitasi pemulihan hubungan dan kesejahteraan emosi. Memaafkan sebagai proses yang melibatkan 'restorasi keseimbangan, menyalahkan dan merujukkan'. Dalam menerima situasi dan memaafkan melibatkan salah satu pasangan (termasuk diri kita sendiri), kita melindungi diri kita sendiri dari rasa sakit yang berlebih.

\section{Kerangka Coaching Pasangan}

\section{Komitmen}

'Setiap pasangan menjadi tahu dan menghormati diri mereka sendiri melalui komitmen mereka membentuk visi bersama yang didukung oleh diri mereka sendiri', maka mereka dapat menguasai hubungan mereka dan mengeluarkan perasaan yang terperangkap dalam hubungan tersebut.

'Menjelaskan tentang komitmen terhadap pasangan dapat mengubah bagaimana pasangan berpikir, merasa, dan berbicara tentang hubungan mereka'. Pasangan sebaiknya tidak terlihat sebagai dua individual dengan tujuan yang terpisah tetapi sebagai kesatuan yang berjuang satu sama lain untuk mencapai tujuan bersama dan tujuan individual mereka.

Cox (2013) menjelaskan bahwa coaching itu sendiri merupakan satu 'co-construction': 
'sebuah mem lebih baik dibandingkan dengan memproduksi ulang'. Ada kedinamisan dalam kerja yang membuat sesuatu hal yang baru, pemahaman bersama yang bisa membawa pasangan melangkah maju.

Coach tidak perlu mengetahui apa yang salah dengan hubungan untuk menguatkan hubungan tersebut. Relationship coaching jangan sampai menuangkan konsentrasi yang berlebih pada apa yang terlihat salah dalam hubungan. Kita mungkin tidak perlu tahu dan menyelesaikan detail dari ketidalsepahaman pasangan, seperti halnya kita tidak perlu membuang kegelapan sebelum kita bisa melihat cahaya. Coach dapat percaya pada konstruktivis, pendekatan goalfocused dimana aspirasi baru didiskusikan dan dideskripsikan dalam metode dari pencapaian yang dibawa ke dalam fokus. Lima kemungkinan skenario yang muncul :

1. Keduanya tidak berubah maka perbedaan di antara realita dan harapan masing-masing tetap beranjut.

2. Pasangan $A$ merubah visinya untuk setara dengan visi pasangan $B$ di dalam hubungan.

3. Pasangan B merubah visinya agar setara dengan visi pasangan A di dalam hubungan.

4. Keduanya merubah visinya masing-masing untuk meraih visi bersama dalam hubungan.

5. Pasangan merubah visinya dalam hubungan untuk menyesuaikan dengan situasi yang ada sekarang

\section{Keterbukaan \& Memahami}

Harus hadir untuk meyakinkan keterbukaan. Sesaat setelah komitmen dan keterbukaan terlah terjalin, usaha untuk menambah pemahaman dan komunikasi antara pasangan akan mempunyai pondasi yang lebih sulit. Bolstad (n.d.) merubah kemampuan komunikasi tergantung pada pemeriksaan awal di dalam pemahaman kami untuk melihat entah saat ini, masing-masing pasangan sebetulnya memiliki keadaan internal dia saat ini dan entah keadaan saat ini adalah keadaan ang diinginkan. Pemeriksaan ini mengidentifikasikan apakah ada masalah dan siapa yang memiliki masalah tersebut.

Bolstad (n.d) mengatakan bahwa alternating di antara 'I message' dan mendengar reflektif sebuah two step dance dibentuk untuk merubah komunikasi pasangan. Proses ini menghasilkan 3 outcome :

1. Kesalahpahaman terpecahkan

2. Konflik kebutuhan dapat teridentifikasi yang mana bisa ditangani melalui 6 langkah winwin model dari resolusi konflik : mengidentifikasikan masalah atau isu; mengevaluasi dalam hal dua set kebutuhan lebih baik dibanding dua solusi yang rumit; solusi yang potensial bisa bertemu dengan dua set kebutuhan; memilih solusi untuk dibentuk menjadi sebuah aksi; bertindak, dan mengevaluasi hasilnya.

3. Konflik melibatkan kepercayaan yang paling dalam dan nilai-nilai. 
Mendengarkan yang reflektif melibatkan pengemukakan kembali pengalaman, opini dan perasaan orang lain di dalam kata-kata yang sama dengan mereka. Faktanya, penelitian Gottman membuktikan bahwa mendengarkan yang reflektif adalah respon yang sangat kuat yang ditawarkan dari orang-orang yang mempunya hubungan yang sukses $\left(^{*}\right)$. Cox mengatakan bahwa mendengarkan yang reflektif disamakan dengan parafrase dan penyimpulan yang mana keduanya adalah bentuk dari menenangkan orang bahwa kata-kata mereka telah didengar. Parafrase, seperti mendengarkan reflektif membolehkan pendengar dapat merevisi kalimat sampai nilai yang benar tercipta di antara keduanya. Hal itu melibatkan kesempatan untuk kejelasan yang lebih besar, diberikan sebagai sebuah hadiah untuk pembicara yang pada saat bersamaan memberikan izin untuk melangkah lebih maju dengan beberapa detail yang baru. Hal itu sangat membantu pasangan untuk saling memahami perspektif satu sama lain. Mendengar secara aktif juga memperlihatkan empati karena hal itu menunjukkan kepada pembicara bahwa perspektif mereka mulai dapat dipahami yang mana itu menguatkan hubungan mereka. Gottman dan Silver (1999: 149) mengatakan bahwa pasangan perlu membuat masing-masing merasa dipahami dan juga melibatkan cara kita melihat orang lain dan benar-benar menganggap perasaan dan perbedaan mereka ke dalam pribadinya.

\section{Performa}

Kemampuan Non-violent communication (NVC) berdasarkan gagasan konflik dari miskomunikasi kebutuhan manusia yang sesungguhnya, yang mana setiap harinya interaksi sering berkedok di dalam tuntutan atau bahasa-bahasa judgemental (Rosenberg, 2003). NVC pendukung komunikasi yang membawa kebutuhan, perasaan, persepsi, dan pernyataan. Hal itu juga mendukung pendekatan empatetik, karena itu mengakui bahwa orang lain mempunyai perasaan dan kebutuhan. NVC dapat sangat berguna dalam alat-alat berkomunikasi untuk mendapatkan kebutuhan sementara pada individu, tetapi di dalam konteks relationship coaching itu didukung oleh komitmen kepada visi bersama.

\section{Belajar Bersama}

Transformasi bisa didapat dari menolong pasangan untuk merefleksikannya di dalam pengalaman mereka tetapi lalu untuk berpikir kritis tentang bagaimana mereka melihat, berpikir dan bertindak sebagai pasangan, termasuk intergrasi elemen bayangan seperti yang disampaikan oleh Batthyany-De La Lama et al. (2012). Selama proses ini mereka menjadi sadar bagaimana sosial dan lingkungan memiliki dampak pada hubungan mereka dan melatih respon mereka dan menemukan jalan untuk menjadikan sebuah hasil dalam perubahan untuk hubungan mereka. Peran coach adalah untuk membentuk ruang yang dapat membangun percakapan pada pasangan. Pengalaman mereka dan dari sana mereka mengeksplorasi kemungkinan yang baru.

\section{Perubahan}

Ada dua cara, yang pertama adalah konsolidasi performa hubungan yang telah mereka bangun, menguatkan cara mereka bekerjasama sebagai pasangan. Yang kedua menuru Batthyany- 
De La Lama menyebutkan bahwa untuk fokus pada pembaharuan dan penyelesaian. Tingkatan pembaharuan dan penyelesaian melibatkan pasangan di dalam evaluasi ulang yang berlanjut dalam hubungan mereka, filosofi hidup mereka, dan tujuan mereka. Tujuannya adalah untuk membangun lapangan yang interaktif dengan kesadaran yag baru, konten, kasih sayang dan kepedulian.

Banyak coach mengungkapkan bahwa mereka menggunakan pendekatan dalam program Coaching mereka, mengacu pada teori perkembangan orang dewasa yang mengadopsi pendekatan terstruktur terhadap pertumbuhan kognitif dan kematangan klien (Fitzgerald dan Berger 2002), teori berdasarkan tahap kehidupan (Palmer dan Panchal 2011), atau teori pengembangan ego (Bachkirova 2011).

Perkembangan orang dewasa (adult development) bisa digambarkan sebagai output alami pemikiran. Ini adalah transformasi proses seumur hidup yang terjadi dengan atau tanpa program Coaching. Hal ini terjadi sebagai akibat dari perubahan melalui pengalaman hidup kita. Perkembangan orang dewasa (adult development) adalah apa yang biasanya terjadi sebagai akibat dari peristiwa kehidupan. Pembelajaran terjadi ketika pengalaman menjadi diserap dan menjadi bagian dari pengalaman efektif (Cox 2013). Taylor et al. (2000: 10) menyimpulkan bahwa perkembangan orang dewasa (adult development) sebagai proses perubahan kualitatif dalam sikap, nilai-nilai dan pemahaman bahwa orang dewasa mengalami akibat dari transaksi yang berkelanjutan dengan lingkungan sosial mereka.

Sehingga, pendekataan developmental coaching pembinaan perkembangan merupakan elemen kunci dari Relationship Coaching, dan bekerja bersama-sama dengan pendekatan goalfocused coaching. Dalam pendekataan developmental coaching, kehidupan dipandang secara eksplisit sebagai perjalanan terus menerus yang dapat didukung, ditingkatkan, dan bahkan mungkin dipercepat melalui proses Coaching. Selama perjalanan mereka, klien dapat didorong dan didukung untuk berpikir tentang sudut pandang yang berbeda dan memiliki pemahaman mereka sendiri dan ditantang untuk memperluas mereka sudut pandang. Pembelajaran merupakan aspek kunci dari proses ini, dan kesadaran juga memainkan bagian. Ryan dan Deci (2000) menunjukkan bagaimana perhatian penuh (mindfulness) yang didapatkan dalam proses Coaching penting dalam memisahkan orang-orang dari pikiran mereka yang otomatis, kebiasaan, dan pola perilaku yang tidak diinginkan, Sehingga memainkan peran dalam membina peningkatan regulasi diri dan sesuatu yang berhubungan dengan peningkatan kesejahteraan.

\section{Penutup}

Inti dari Relationship Coaching adalah bekerja dengan klien untuk mengidentifikasi apa kendala dalam menjalin hubungan selama ini di mana area untuk pengembangan pribadi yang mungkin berguna untuk mencapai tujuan keberhasilan hubungan. Namun, sebelum program Coaching dimulai, sangat penting untuk membangun hubungan pembinaan (coaching relation), yaitu memungkinkan 
aliansi pembinaan yang hangat dan produktif. Melalui praktek relationship coaching, individu berhasil meningkatkan pemahaman mengenai masalah hubungannya. Relationship coaching adalah tentang meningkatkan kemampuan coachee untuk berdiri kembali dan melihat lebih objektif pada kehidupannya.

Relationship coaching dapat meningkatkan hubungan individu dengan pasangannya melalui pemeriksaan nilai-nilai, keyakinan, dan asumsi serta keterbukaan dalam komunikasi. Hasilnya, individu mencapai pemahaman yang lebih mengenai diri mereka sendiri, mengenai pasangan mereka, dan hubungan mereka. Termasuk pendekatan 'pembentukan komunikasi' untuk membantu pasangan meningkatkan komunikasi mereka.

\section{Daftar Pustaka}

Arnold.J.(2009).Coaching Skills for Leaders in the workplace. United Kingdom: How To Content.

Bachkirova, T. \& Cox E. (2007) A cognitive-developmental approach for coach development. In: Palmer, S. \& Whybrow, A. eds. Handbook of Coaching Psychology: A Guide for Practitioners. London: Routledge.

Bachkirova, T. , Cox, E. , and Clutterbuck, D. ( 2014). Introduction. In E. Cox , T. Bachkirova , and D. Clutterbuck (Eds), The complete handbook of coaching (pp. 1- 18), London: Sage.

Baumeister, R. F. \& Vohs, K. D. (2007) Handbook of self-regulation. New York, N.Y: Guilford

Baumeister, R. F. , and Leary, M. R. ( 1995). The need to belong: Desire for interpersonal attachments as a fundamental human motivation . Psychological Bulletin, 117, 497- 529.

Coaching Indonesia. (2016). Coaching Global Movement. Bahan Ajar Perkuliahan : Tidak diterbitkan.

Cox, E. \& Jackson (2010) Developmental coaching. In: Cox, E., Bachkirova, T. \& Clutterbuck, D. eds. The Sage Handbook of Coaching. London: Sage.

Cupach , W. R., and Spitzberg , B. H. (Eds) ( 2011 ). The dark side of close relationships - II . New York : Routledge .

C78. www.republika.co.id (14 November 2014). Tingkat Perceraian Indonesia Meningkat Setiap Tahun, ini Datanya.

Erikson, E. H. ( 1959 ). Identity and the life cycle. New York : Norton.

Fitzgerald, C. and Berger, J. (2002) Leadership and complexity of mind: the role of and perspectives. Palo Alto, CA: Davies-Black. executive coaching. In C.

Garnefski.N,Kraaij.V, P.Spinhoven.(2001) Negative life events, cognitive emotion regulation and emotional problems.Journal of Personality and Individual Differences 30,1311.

Goodman, R. (2002) in F itzgerald, C. \& Berger, J. (Eds) Executive Coaching: Practices \& Perspectives, Palo Alto: Davies-Black Publishing. 
Gottman, J., \& Silver, N. (1999). The Seven Principles for Making Marriage Work. New York: NY: Three Rivers.

Gottmann, J.M. (1993). A theory of marital dissolution and stability. American Psychological Association. Journal of Family Psychology Vol. 7, No. 1, 57-75.

Grant, A.M. (2003). The impact of life coaching on goal attainment, metacognition and mental health. Social Behaviour and Personality: An International Journal, 31(3), 253.

Grant, A.M. (2006). An integrative goal-focused approach to executive coaching. In D. Stober \& A.M. Grant (Eds.), Evidence based coaching handbook (pp.153). New York: Wiley.

Hall, L.M. \& Duval, M. (2004) Meta-coaching: Coaching change, 1. Clifton: Neuro Semantics Publications.

Hudson, F. M. (1999) The handbook of coaching: A comprehensive resource guide for managers, executives, consultants and human resource professionals. Jossey-Bass, San Francisco.

Ives, Y. (2008) What is 'coaching'? An exploration of conflicting paradigms. InternationalJournal of Evidence Based Coaching and Mentoring, 6(2) August, 100-113

Ives , Y. ( 2011 ). What is relationship coaching? International Journal of Evidence BasedCoaching and Mentoring, 10 ( 2), 88 - 99

Ives, Yossi. (2012). What is Relationship Coaching. International Journal of Evidence Based Coaching and Mentoring. Vol. 10, No. 2, August 2012, Page 88.

Ives , Y. , and Cox , E. ( 2015 ). Relationship Coaching: The Theory and Practice of Coaching With Singles, Couples and Parents. International Journal of Evidence Based Coaching and Mentoring.

Kaplan and Manuck (1994). Antiatherogenic effects of $\beta$-adrenergic blocking agents: Theoretical, experimental, and epidemiologic considerations. American Heart Journal, 128(6) Part 2, $1316-1328$.

Kegan, R. (1982) The Evolving Self: Problem and process in human development. London Press.

Knowles, M., Holton, E.F. III \& Swanson, R.A. (2005). The adult learner: The definitive classic in adult education and human resource development. 6th ed. Burlington: Elsevier.

Latham, G. P. (2007) Work motivation: History, theory, research, and practice. 19 London: Sage

Miser, A. L., and Miser, M.F (2008).Couples coaching for expatriate couples. In M.Moral and G Abbott (Eds), The Rouledge companion to international business coaching. Abingdon.UK: Routledge.

Myers , D. G. , and Diener , E. ( 1995 ). Who is happy? Psychological Science , 6 , 10 - 19 .

Nelson-Jones , R. ( 2006 ). Human relationship skills: Coaching and self-coaching . London : 
Routledge.

O'Connell, B. \& Palmer, S. (2007) Solution-focused coaching. In: Palmer, S. \& Whybrow, A. eds. Handbook of Coaching Psychology: A Guide for Practitioners. London: Routledge.

Parsloe, E. \& Wray, M. (2000) Coaching and mentoring, London: Kogan Page.

Rosenberg.M.B. (2003) NVC Introduction to Non-Violen Communication -Language for life. Encintas, CA: PuddleDancer.

Schwarzer , R. , and Leppin , A. ( 1992 ). Social support and mental health: A conceptual and empirical overview . In L. Montada , S.-H. Filipp, and M. J. Lerner (Eds), Life crises andexperiences of loss in adulthood (pp. $435-458$ ). Hillsdale, NJ : Erlbaum .

Szabo, P. \& Meier, D. (2009) Coaching: Plain and simple. New York: W. W. Norton \& Co

Sills, Charlotte. (2003). Towards the coaching relationship. This article was published in Training Magazine : UK.

Stewart, L.J., Palmer, S., Wilkin, H. \& Kerrin, M. (2008) The influence of character: Does personality impact coaching success? International Journal of Evidence Based Coaching and Mentoring, 6(1) February, 32-43 